\title{
THE EFFECT OF SOIL CONDITIONERS ON CELLULOSE, HEMICELLULOSE, AND THE ADL FIBRE FRACTION CONCENTRATION IN DACTYLIS GLOMERATA AND LOLIUM PERENNE
}

\author{
Milena Truba', Beata Wiśniewska-Kadżajan', Jacek Sosnowski', \\ Elżbieta Malinowska', Kazimierz Jankowski' , Artur Makarewicz ${ }^{2}$
}

\footnotetext{
1 Department of Grasslands and Landscape Architecture Development, University of Humanities and Life Sciences in Siedlce, Konarskiego 2, 08-110 Siedlce, Poland, e-mail: milena.truba@uph.edu.pl

2 Department of Agrotechnology, University of Humanities and Life Sciences in Siedlce, Poland
}

Received: 2016.08 .16 Accepted: 2016.10 .23 Published: 2017.01.01

\begin{abstract}
Replicated three times, the research was conducted in the experimental field between 2011 and 2014. Three soil conditioners with the following trade names: UGmax, EkoUżyźniacz, and Humus Active Papka were used in the experiment, separately or together with NPK fertilisers. They were all used on plots sown with two species of grass, Dactylis glomerata of the Bora variety and Lolium perenne of the Info variety. The plant material from both grass species was tested for the concentration of ADL fraction $(\% \mathrm{DM})$, cellulose $(\% \mathrm{DM})$, and hemicellulose $(\% \mathrm{DM})$. It was found that the concentration of cellulose, hemicelluloses, and the ADL fraction was significantly higher in the biomass of Dactylis glomerata than in the biomass of Lolium perenne. The grass from the plot with the UGmax soil conditioner applied had the highest amount of cellulose and hemicellulose. The lowest amount of those organic compounds was found in the grass treated with UGmax together with mineral fertilisers and in plants treated with Humus Active, together with mineral fertilisers. However, the fertilisers and conditioners did not increase the ADL content in both grass species.
\end{abstract}

Keywords: cellulose, hemicellulose, Acid Detergent Lignin, Dactylis glomerata, Lolium perenne

\section{INTRODUCTION}

Feed intake, its digestibility, and energy value depend on the content of cellulose, hemicelluloses, and lignin [Baert and Van Waes 2014, Belanger et al. 2013]. All the three substances are components of the Neutral Detergent Fibre (NDF). Neutral detergent dissolves the inside of the cell and cellulose, hemicelluloses, and lignin are left behind. During a treatment of the NDF fraction with an acid detergent, hemicellulose is dissolved and Acid Detergent Fibre (ADF) is isolated. Thus, Acid Detergent Fibre contains cellulose and lignin. Further on, when ADF is treated with $72 \%$ sulphuric acid, cellulose and protein are dissolved and Acid Detergent Lignin (ADL) is left behind, together with cutin and ash [Brzóska 2001]. Cell wall components, such as cellulose and hemicelluloses, can be digested by animals to some extent, but lignin is indigestible. In turn, cellulose is digested by animals more slowly than hemicellulose [Kotlarz et al. 2010, Thomet et al. 2011]. Structural fibber content is different in different parts of plants. The highest content of cellulose and lignin is in the grass stems and the lowest in grass blades, which means that the latter ones are more digestible. Florescence, in turn, contains the lowest amount of lignin [Kozłowski et al. 1996].

There has been a lack of research on the effect of soil conditioners on the content of cellulose, hemicelluloses, and the ADL fraction in plants, particularly in fodder grass. Because of that it had been decided to study the change of the content of cellulose, hemicelluloses, and the ADL fraction 
in two grass species, Dactylis glomerata and Lolium perenne, after application of soil conditioners used solely or together with mineral fertilisers.

\section{MATERIALS AND METHODS}

Replicated three times, the experiment was set up in the experimental field of the Department of Grasslands and Landscape Architecture Development at the University of Natural Sciences and Humanities in Siedlce $\left(52.169^{\circ} \mathrm{N} .22 .280^{\circ} \mathrm{E}\right)$. According to the Polish classification system (2011), the soil on which it was carried out was of the order of anthrosole and the type of hortisole, formed from light loamy sand (Table 1).

The analysis carried out at the Regional Chemical Station in Wesoła found that the soil was of neutral $\mathrm{pH}(\mathrm{pH}=6.8)$, with assimilable phosphorus in a form of $\mathrm{H}_{2} \mathrm{PO}_{4}^{-}$standing at 170 $\mathrm{mg} \cdot \mathrm{kg}^{-1}$, magnesium $\mathrm{Mg}^{2+}$ at $84 \mathrm{mg} \cdot \mathrm{kg}^{-1}$, potassium $\mathrm{K}^{+}$at $114 \mathrm{mg} \cdot \mathrm{kg}^{-1}$, total nitrogen $\mathrm{N}$ at 1.3 $\mathrm{g} \cdot \mathrm{kg}^{-1}$, and organic carbon at $13.5 \mathrm{~g} \cdot \mathrm{kg}^{-1} \mathrm{DM}$.

Soil conditioners with the trade names of UGmax, Eko-Użyźniacz, and Humus Active Papka, applied separately or together with mineral fertilisers, were used in the experiment. The active ingredients of those conditioners are presented in Table 2. Those conditioners were applied every year at the beginning of the growing season at the following doses: Ugmax $-0.61 \cdot \mathrm{ha}^{-1}$, EkoUżyźniacz - 15 1·ha ${ }^{-1}$, Humus Active Papka - $50 \mathrm{l} \cdot \mathrm{ha}^{-1}$. Nitrogen $\left(15 \mathrm{~kg} \mathrm{~N} \cdot \mathrm{ha}^{-1}\right)$ and potassium $\left(120 \mathrm{~kg} \mathrm{~K}_{2} \mathrm{O} \cdot \mathrm{ha}^{-1}\right)$ fertilisers were used in three doses, while phosphorus $\left(80 \mathrm{~kg} \mathrm{P}_{2} \mathrm{O}_{5} \cdot \mathrm{ha}^{-1}\right)$ only once a year. The test plants in the experiment

Table 1. Soil granulometric composition

\begin{tabular}{|c|c|c|c|}
\hline \multicolumn{4}{|c|}{ Percentage of particle fractions $(\mathrm{mm})$} \\
\hline $2.0-0.05$ & $0.05-0.002$ & $>0.002$ & Granulometric group \\
\hline 85 & 13 & 2 & Loamy sand \\
\hline
\end{tabular}

were the Bora variety of Dactylis glomerata and the Info variety of Lolium perenne. They were sown in the autumn of 2011 on $3 \mathrm{~m}^{2}$ plots with the seeding rate of 18 and $23 \mathrm{~kg} \cdot \mathrm{ha}^{-1}$, respectively.

Throughout the three-year experiment the grass was harvested three times a year. From each cut, plants were sampled for chemical analysis. The ADL fraction content was measured with near-infrared spectroscopy (NIRS) by the Institute of Technology and Life Sciences in Falenty, using the NIRFlex N-500 spectrometer, with the INGOT calibration package for dry feed. Cellulose and hemicellulose content was determined with the method of Van Soest et al. [1991].

The Hydrological and Meteorological Station in Siedlce provided data used to calculate Sielianinov's hydrothermal coefficient (Table 3) showing changing weather conditions and soil moisture and their effect on plant growth [Bac et al. 1993].

In the first year of the experiment (2012) optimal weather conditions and optimal soil moisture were only in June and October, with drought to extreme drought throughout the rest of the season. In the next experimental years dry periods were followed by wet ones, with the best conditions only in April 2013, April 2014, and in July 2013. Generally, every year the conditions were better during the first few months of the experiment.

\section{RESULTS}

\section{Cellulose content}

According to Choct [1997], cellulose is made up of repeating units of glucose, while Annison [1993] points out that it is the main ingredient of cell walls. Bach Knudsen holds [1997] that the structure of cellulose prevents molecules of water from entering inside, which makes it insoluble. According to Jankowska-Huflejt and Wróbel

Table 2. Ingredients of the soil conditioners

\begin{tabular}{|c|c|c|c|c|c|c|c|c|c|c|c|}
\hline \multirow{2}{*}{ Product } & \multicolumn{6}{|c|}{ Macroelements $\left(\mathrm{g} \cdot \mathrm{kg}^{-1}\right)$} & \multicolumn{4}{|c|}{$\begin{array}{l}\text { Microelements } \\
\left(\mathrm{mg} \cdot \mathrm{kg}^{-1}\right)\end{array}$} & \multirow{2}{*}{ Microorganisms and others } \\
\hline & $\mathrm{N}$ & $\mathrm{P}$ & $\mathrm{K}$ & $\mathrm{Ca}$ & $\mathrm{Mg}$ & $\mathrm{Na}$ & $\mathrm{Mn}$ & $\mathrm{Fe}$ & $\mathrm{Zn}$ & $\mathrm{Cu}$ & \\
\hline UGmax & 1.2 & 0.2 & 2.9 & - & 0.1 & 0.2 & 0.3 & - & - & - & $\begin{array}{l}\text { lactic acid bacteria, photosynthetic } \\
\text { bacteria, Azotobacter, } \\
\text { Pseudomonas, yeast, actinomycetes }\end{array}$ \\
\hline Eko-Użyźniacz & 0.6 & 0.3 & 0.7 & - & - & - & - & - & - & - & $\begin{array}{l}\text { endomycorrhizal fungi, bacteria, } \\
\text { earthworm fibrinolytic enzymes }\end{array}$ \\
\hline $\begin{array}{l}\text { Humus Active } \\
\text { Papka }\end{array}$ & 0.2 & 1.3 & 4.6 & 3.0 & 0.5 & - & 15 & 500 & 3 & 1 & $\begin{array}{l}\text { active humus and population of } \\
\text { useful microorganisms }\end{array}$ \\
\hline
\end{tabular}


Table 3. Sielianinov's hydrothermal coefficient values during the growing season

\begin{tabular}{|c|c|c|c|c|c|c|c|}
\hline \multirow{2}{*}{ Years } & \multicolumn{7}{|c|}{ Months } \\
\cline { 2 - 8 } & Apr. & May & June & July & Aug. & Sept. & Oct. \\
\hline 2012 & $1.12(\mathrm{md})$ & $1.22(\mathrm{md})$ & $1.56(\mathrm{o})$ & $0.69(\mathrm{sd})$ & $0.94(\mathrm{~d})$ & $0.27(\mathrm{ed})$ & $1.32(\mathrm{o})$ \\
\hline 2013 & $1.60(\mathrm{o})$ & $2.20(\mathrm{w})$ & $1.80(\mathrm{mw})$ & $1.50(\mathrm{o})$ & $0.25(\mathrm{ed})$ & $2.70(\mathrm{sw})$ & $1.22(\mathrm{md})$ \\
\hline 2014 & $1.53(\mathrm{o})$ & $2.29(\mathrm{w})$ & $1.20(\mathrm{md})$ & $0.16(\mathrm{ed})$ & $1.95(\mathrm{mw})$ & $0.59(\mathrm{sd})$ & $0.13(\mathrm{ed})$ \\
\hline
\end{tabular}

$\mathrm{K} \leq 0.4$ extreme drought (ed), $0.4<\mathrm{K} \leq 0.7$ severe drought (sd), $0.7<\mathrm{K} \leq 1.0$ drought (d), $1.0<\mathrm{K} \leq 1.3$ moderate drought (md), $1.3<\mathrm{K} \leq 1.6$ optimal (o), $1.6<\mathrm{K} \leq 2.0$ moderately wet (mw), $2.0<\mathrm{K} \leq 2.5$ wet (w), $2.5<\mathrm{K} \leq 3.0$ severely wet (sw), K $>3.0$ extremely wet (ew)

[2008] cellulose concentration is the lowest in pasture grass, ranging from 249.8 to $271.0 \mathrm{~g} \cdot \mathrm{kg}^{-1}$ $\mathrm{DM}$, while in meadow grass it varies from 287.7 to $299.7 \mathrm{~g} \cdot \mathrm{kg}^{-1} \mathrm{DM}$, and in hay from 290.4 to $302.7 \mathrm{~g} \cdot \mathrm{kg}^{-1} \mathrm{DM}$.

Analyzing all the experimental units with both of the grass species, during all experimental years, (Table 4) it was observed that the highest cellulose concentration $\left(256.1 \mathrm{~g} \cdot \mathrm{kg}^{-1}\right)$ was in the grass on the plot where UGmax was applied, while the lowest $\left(240.6 \mathrm{~g} \cdot \mathrm{kg}^{-1}\right)$ was in plants from the plot with UGmax together with mineral fertilisers. Ciepiela [2014] has found that mineral nitrogen application can lower cellulose concentration in Dactylis glomerata.

Comparing both of the grass species, Dactylis glomerata had a higher concentration of cellulose $\left(252.8 \mathrm{~g} \cdot \mathrm{kg}^{-1}\right)$ than Lolium perenne $\left(240.8 \mathrm{~g} \cdot \mathrm{kg}^{-1}\right)$. The differences between those species were statistically significant.
The analysis of the results of the experiment showed that for both grass species and all fertiliser combinations (Table 4) the highest cellulose concentration $\left(255.6 \mathrm{~g} \cdot \mathrm{kg}^{-1}\right)$ was in the grass harvested during the third year (2014) and the lowest $\left(238.9 \mathrm{~g} \cdot \mathrm{kg}^{-1}\right)$ in the grass of the second year (2013). Additionally, the average cellulose concentration in the third year (2014) was significantly higher than in the first or second year (2012 and 2013). Cell walls in young plants are built of cellulose mainly but in older ones its micelles are impregnated with lignin. It is a result of the process of lignification, an inseparable part of plant senescence [Bach Knudsen 1997]. A very high concentration of cellulose in the third year of the experiment was probably an effect of an early grass harvest, optimal weather conditions as well as optimal soil moisture, which all made the conversion of cellulose into lignin slower.

Table 4. Relationship between cellulose concentration in the dry matter $\left(\mathrm{g} \cdot \mathrm{kg}^{-1}\right)$, the fertilisers, and experimental year

\begin{tabular}{|c|c|c|c|c|c|c|c|c|c|c|}
\hline \multirow{2}{*}{$\begin{array}{l}\text { Species } \\
\text { (B) }\end{array}$} & \multirow{2}{*}{$\begin{array}{l}\text { Year } \\
\text { (C) }\end{array}$} & \multicolumn{8}{|c|}{ Effect of fertiliser treatment $(\mathrm{A})$} & \multirow{2}{*}{ Average } \\
\hline & & 0 & NPK & UG & EU & $\mathrm{HA}$ & UG+NPK & EU+NPK & $\mathrm{HA}+\mathrm{NPK}$ & \\
\hline \multirow{3}{*}{$\begin{array}{l}\text { Dactylis } \\
\text { glomerata }\end{array}$} & 2012 & 270.6 & 263.9 & 266.5 & 260.3 & 235.7 & 239.6 & 262.2 & 240.7 & 254.9 \\
\hline & 2013 & 245.0 & 252.2 & 256.3 & 235.2 & 255.5 & 251.3 & 246.8 & 238.8 & 247.6 \\
\hline & 2014 & 252.4 & 253.7 & 259.6 & 261.8 & 261.4 & 251.4 & 248.0 & 259.2 & 255.9 \\
\hline \multirow{3}{*}{$\begin{array}{l}\text { Lolium } \\
\text { perenne }\end{array}$} & 2012 & 235.8 & 251.5 & 245.2 & 235.9 & 244.0 & 211.2 & 237.2 & 233.4 & 236.8 \\
\hline & 2013 & 222.0 & 230.6 & 245.0 & 219.7 & 224.4 & 234.4 & 242.3 & 222.4 & 230.1 \\
\hline & 2014 & 243.1 & 271.3 & 263.8 & 248.8 & 255.4 & 255.4 & 262.3 & 259.6 & 257.5 \\
\hline \multicolumn{11}{|c|}{ Average effect of fertiliser treatment } \\
\hline \multicolumn{2}{|c|}{ Fertilisers } & 244.8 & 253.9 & 256.1 & 243.6 & 243.3 & 240.6 & 249.8 & 242.3 & 246.8 \\
\hline \multicolumn{11}{|c|}{ Average concentration by species } \\
\hline \multicolumn{2}{|c|}{ Dactylis glomerata } & 256.0 & 256.6 & 260.8 & 252.4 & 250.9 & 247.4 & 252.3 & 246.2 & 252.8 \\
\hline \multicolumn{2}{|c|}{ Lolium perenne } & 233.6 & 251.1 & 251.4 & 234.8 & 235.7 & 233.7 & 247.3 & 238.4 & 240.8 \\
\hline \multicolumn{11}{|c|}{ Average concentration by year } \\
\hline \multicolumn{2}{|c|}{2012} & 253.2 & 257.7 & 255.9 & 248.1 & 239.9 & 225.4 & 249.7 & 237.0 & 245.9 \\
\hline \multicolumn{2}{|c|}{2013} & 233.5 & 241.4 & 250.7 & 227.4 & 240.2 & 242.9 & 244.6 & 230.6 & 238.9 \\
\hline \multicolumn{2}{|c|}{2014} & 247.8 & 262.5 & 261.7 & 255.3 & 249.8 & 253.4 & 255.2 & 259.4 & 255.6 \\
\hline
\end{tabular}

NS - not significant 


\section{Hemicellulose content}

Like cellulose, hemicellulose is an important component of the cell wall [Vasiljevic et al. 2008]. According to Bach Knudsen [1997] hemicellulose is present in plant tissues along with cellulose and is one of the forms in which plants store energy. Hemicellulose consists mainly of pentose and hexose, and in the cell wall its chains are bound to cellulose.

Throughout the experiment for both of the species and all fertiliser combinations the highest concentration of hemicellulose $\left(176.2 \mathrm{~g} \cdot \mathrm{kg}^{-}\right.$ $\left.{ }^{1}\right)$ was in the grass from the plots with UGmax (Table 5), while the lowest $\left(141.7 \mathrm{~g} \cdot \mathrm{kg}^{-1}\right)$ in the grass with Humus Active applied together with mineral fertilisers. Those differences were not statistically significant.

Comparing hemicellulose concentration in both of the species (Table 5) it was found that it was higher in Dactylis glomerata $(172.5$ $\left.\mathrm{g} \cdot \mathrm{kg}^{-1}\right)$ than in Lolium perenne $\left(149.7 \mathrm{~g} \cdot \mathrm{kg}^{-1}\right)$. The differences between hemicellulose concentration were statistically significant.

Throughout the experiment, for both of the species and all fertiliser combinations (Table 5) hemicellulose concentration was growing all the time. Consequently, the highest (170.9 $\mathrm{g} \cdot \mathrm{kg}^{-1}$ ) was in the grass in the third year (2014), and the lowest $\left(147.9 \mathrm{~g} \cdot \mathrm{kg}^{-1}\right)$ in the first year (2012) of the experiment.

\section{Concentration of Acid Detergent Lignin (ADL)}

ADL (Acid Detergent Lignin) concentration in a plant is an indicator of how far the process of lignification is advanced [Kotlarz at al. 2010]. Analysing all forms of fertiliser treatment throughout the experiment for both of the grass species, the highest concentration of the ADL fraction $\left(42.9 \mathrm{~g} \cdot \mathrm{kg}^{-1}\right)$ was in the grass on the plot with mineral fertilisers (Table 6 ), and the lowest $\left(40.6 \mathrm{~g} \cdot \mathrm{kg}^{-1}\right)$ on the plot with Humus Active. Those differences were not statistically significant.

Of all experimental plots and all experimental years the average concentration of the ADL fraction (Table 6) was significantly higher in Dactylis glomerata $\left(42.5 \mathrm{~g} \cdot \mathrm{kg}^{-1}\right)$ than in Lolium perenne $\left(41.2 \mathrm{~g} \cdot \mathrm{kg}^{-1}\right)$. Baert at al. [2012] found much lower concentration of the ADL fraction in Lolium perenne (from 23 to $\left.26 \mathrm{~g} \cdot \mathrm{kg}^{-1}\right)$, while in the case of Dactylis glomerata (from 36 to $39 \mathrm{~g} \cdot \mathrm{kg}^{-1}$ ) it was similar to that found in the present experiment.

Of all the experimental years (Table 6) the highest concentration of the ADL fraction (43.9 $\left.\mathrm{g} \cdot \mathrm{kg}^{-1}\right)$ was in the second year (2013),

Table 5. Relationship between hemicellulose concentration in the dry matter $\left(\mathrm{g} \cdot \mathrm{kg}^{-1}\right)$, the fertilisers, and experimental year

\begin{tabular}{|c|c|c|c|c|c|c|c|c|c|c|}
\hline \multirow{2}{*}{$\begin{array}{c}\text { Species } \\
\text { (B) }\end{array}$} & \multirow{2}{*}{$\begin{array}{l}\text { Year } \\
\text { (C) }\end{array}$} & \multicolumn{8}{|c|}{ Effect of fertiliser treatment (A) } & \multirow{2}{*}{ Average } \\
\hline & & 0 & NPK & UG & EU & $\mathrm{HA}$ & UG+NPK & EU+NPK & $\mathrm{HA}+\mathrm{NPK}$ & \\
\hline \multirow{3}{*}{$\begin{array}{c}\text { Dactylis } \\
\text { glomerata }\end{array}$} & 2012 & 177.9 & 188.3 & 184.8 & 149.6 & 130.4 & 159.0 & 172.5 & 139.8 & 162.8 \\
\hline & 2013 & 177.2 & 205.0 & 208.6 & 145.0 & 174.2 & 195.2 & 214.8 & 165.1 & 185.6 \\
\hline & 2014 & 173.6 & 183.5 & 152.0 & 149.3 & 185.4 & 168.9 & 167.8 & 171.1 & 169.0 \\
\hline \multirow{3}{*}{$\begin{array}{l}\text { Lolium } \\
\text { perenne }\end{array}$} & 2012 & 145.1 & 139.0 & 158.4 & 131.5 & 132.7 & 132.5 & 122.9 & 101.6 & 133.0 \\
\hline & 2013 & 122.1 & 137.4 & 142.4 & 158.7 & 180.5 & 150.7 & 118.6 & 135.3 & 143.2 \\
\hline & 2014 & 159.6 & 182.1 & 210.9 & 212.5 & 184.8 & 123.4 & 172.4 & 137.2 & 172.9 \\
\hline \multicolumn{11}{|c|}{ Average effect of fertiliser treatment } \\
\hline Fertilis & & 159.3 & 172.5 & 176.2 & 157.8 & 164.7 & 155.0 & 161.5 & 141.7 & 161.1 \\
\hline \multicolumn{11}{|c|}{ Average concentration by species } \\
\hline Dactylis glo & nerata & 176.2 & 192.2 & 181.8 & 148.0 & 163.3 & 174.4 & 185.0 & 158.7 & 172.5 \\
\hline Lolium pe & enne & 142.3 & 152.8 & 170.6 & 167.6 & 166.0 & 135.5 & 138.0 & 124.7 & 149.7 \\
\hline \multicolumn{11}{|c|}{ Average concentration by year } \\
\hline 2012 & & 161.5 & 163.6 & 171.6 & 140.5 & 131.6 & 145.7 & 147.7 & 120.7 & 147.9 \\
\hline 2013 & & 149.7 & 171.2 & 175.5 & 151.8 & 177.3 & 172.9 & 166.7 & 150.2 & 164.4 \\
\hline 2014 & & 166.6 & 182.8 & 181.5 & 180.9 & 185.1 & 146.2 & 170.1 & 154.2 & 170.9 \\
\hline
\end{tabular}

NS - not significant 
Table 6. Relationship between ADL concentration in the dry matter $\left(\mathrm{g} \cdot \mathrm{kg}^{-1}\right)$, the fertilisers, and experimental year

\begin{tabular}{|c|c|c|c|c|c|c|c|c|c|c|}
\hline \multirow{2}{*}{$\begin{array}{c}\text { Species } \\
\text { (B) }\end{array}$} & \multirow{2}{*}{$\begin{array}{l}\text { Year } \\
\text { (C) }\end{array}$} & \multicolumn{8}{|c|}{ Effect of fertiliser treatment $(\mathrm{A})$} & \multirow{2}{*}{ Average } \\
\hline & & 0 & NPK & UG & EU & $\mathrm{HA}$ & UG+NPK & EU+NPK & $\mathrm{HA}+\mathrm{NPK}$ & \\
\hline \multirow{3}{*}{$\begin{array}{l}\text { Dactylis } \\
\text { glomerata }\end{array}$} & 2012 & 43.0 & 45.1 & 41.5 & 42.8 & 41.7 & 41.6 & 44.4 & 42.6 & 42.8 \\
\hline & 2013 & 46.7 & 46.7 & 41.7 & 40.0 & 42.0 & 43.7 & 46.3 & 46.4 & 44.2 \\
\hline & 2014 & 42.1 & 41.9 & 41.4 & 40.2 & 40.9 & 38.2 & 40.2 & 38.9 & 20.5 \\
\hline \multirow{3}{*}{$\begin{array}{l}\text { Lolium } \\
\text { perenne }\end{array}$} & 2012 & 41.8 & 41.2 & 41.6 & 41.1 & 36.1 & 39.1 & 38.4 & 40.6 & 40.0 \\
\hline & 2013 & 45.4 & 42.8 & 46.7 & 41.8 & 40.4 & 42.4 & 44.2 & 45.5 & 43.7 \\
\hline & 2014 & 37.0 & 39.9 & 42.2 & 40.0 & 42.2 & 40.2 & 42.2 & 37.5 & 40.2 \\
\hline \multicolumn{11}{|c|}{ Average effect of fertiliser treatment } \\
\hline Nawoż & & 42.6 & 42.9 & 42.6 & 41.0 & 40.6 & 40.9 & 42.6 & 41.9 & 41.9 \\
\hline \multicolumn{11}{|c|}{ Average concentration by species } \\
\hline Dactylis gl & erata & 43.8 & 44.5 & 41.6 & 41.0 & 41.5 & 41.2 & 43.6 & 42.6 & 42.5 \\
\hline Lolium $p$ & nne & 41.4 & 41.3 & 43.5 & 41.0 & 39.6 & 40.6 & 41.6 & 41.2 & 41.3 \\
\hline \multicolumn{11}{|c|}{ Average concentration by year } \\
\hline 201 & & 42.4 & 43.1 & 41.6 & 42.0 & 38.9 & 40.4 & 41.4 & 41.6 & 41.4 \\
\hline 201 & & 45.8 & 44.7 & 44.2 & 40.9 & 41.2 & 43.0 & 45.3 & 45.9 & 43.9 \\
\hline 201 & & 39.5 & 40.9 & 41.8 & 40.1 & 41.6 & 39.2 & 41.2 & 38.2 & 40.3 \\
\hline
\end{tabular}

NS - not significant

while the lowest $\left(40.3 \mathrm{~g} \cdot \mathrm{kg}^{-1}\right)$ in the third year (2014). ADL concentration in the second year was significantly different from the concentration in the first and third year.

As mentioned above, low concentration of the ADL fraction might have resulted from an earlier grass harvest, favourable weather conditions, and favourable soil moisture, which all hindered the process of lignification (2014).

\section{CONCLUSIONS}

1. The concentration of cellulose, hemicellulose, and the ADL fraction was significantly higher in the biomass of Dactylis glomerata than in Lolium perenne.

2. The UGmax soil conditioner applied without mineral fertilisers increased cellulose and hemicellulose concentration in the grass.

3. Application of UGmax and Humus Active Papka together with mineral fertilisers limited cellulose and hemicellulose concentration in both of the grass species.

4. Mineral fertilisers did not affect ADL concentration in both of the grass species in a significant way.

\section{REFERENCES}

1. Annison G. 1993. The chemistry of dietary fiber. In: Dietary Fiber and Beyond - Australian Perspectives. Eds. S. Samman. G. Anisson. Asia Pacific Journal of Unical Nitrition, 1-18.

2. Bac S., Koźmiński C., Rojek M. 1993. Agrometeorologia. Państwowe Wydawnictwo Naukowe. Warszawa, 32-33.

3. Bach Knudsen K.E. 1997. Carbohydrate and lignin contents of plant materials used in animal feeding. Animal Feed Sciences and Technology, 67(4), 319-338.

4. Baert J., De Vliegher A., Van Hulle S., Van Waes C., Muylle H. 2012. Biomass yield and composition from semi - extensively cultivated perennial fodder grasses. Grassland - a European Resource? EGF, Grassland Sciences in Europe, 17, 460-462.

5. Baert J., Van Waes C. 2014. Improvement of the digestibility of tall fescue (Festuca arundinacea Schreb.) inspired by perennial ryegrass (Lolium perenne L.). The Future of European Grasslands, EGF, Grassland Sciences in Europe, 19, 172-174.

6. Belanger G., Virkajarvi P., Duru M., Tremblay G.F., Saarijarvi K. 2013. Herbage nutritive in less favoured areas of cool regions. The Role of Grasslands in a Green Future, EGF, Grassland Sciences in Europe, 18, 57-70.

7. Brzóska F. 2001. Wprowadzenie do tematyki paszoznawstwa. W: Żywienie zwierząt i paszoznawstwo. Pod Red. D. Jamroz, W. Podkówki i J. Chachułowej. Wyd. PWN. 
8. Choct M. 1997. Feed non - starch polysaccharider: Chemical Structure and Nutritional Significance. Feed Milling International, June Issue, 13-26.

9. Ciepiela A.G. 2014. Zawartość węglowodanów strukturalnych i niestrukturalnych oraz ligniny w Dactylis glomerata L. i Festulolium brauni (K. Richt.) A. Camus zasilanych biostymulatorem Kelpak SL i azotem. Nauka Przyroda Technologie, 8, 1, \#2.

10. Jankowska-Huflejt H., Wróbel B. 2008. Ocena przydatności pasz z użytków zielonych do produkcji zwierzęcej w badanych gospodarstwach ekologicznych. J. Res. Appl. Agr. Eng., 53(3), 103-108.

11. Kotlarz A., Stankiewicz S., Biel W. 2010. Skład botaniczny i chemiczny siana z półnaturalnej łąki oraz jego wartość pokarmowa dla koni. Acta Sci. Pol. Zootechnica, 9(4), 119-128.

12. Kozłowski S., Golińska B., Swędrzyński A., Goliński P. 1996. Szybkość lignifikacji traw. Zesz. Probl. Post. Nauk Rol., 442, 257-268.
13. Systematyka Gleb Polski 2011. Roczniki Gleboznawcze 62,3 .

14. Thomet P., Cutullic E., Bisig W., Wuest C., Elsaesser M., Steinberger S., Steinwidder A. 2011. Merits of full grazing systems as a sustainable and efficient milk production strategy. Grassland Farming and Land Management System in Mountainous Regions, EGF, Grassland Sciences in Europe, 16, 273-285.

15. Van Soest P.J., Robertson J.B., Lewis B.A. 1991. Methods for dietary fiber, neutral detergent fiber, and nonstarch polysaccharides in relation to animal nutrition. Symposium: Carbohydrate methodology, metabolism, and nutritional implications in dairy cattle. Journal of Dairy Science, 74(10), 3583-3597.

16. Vasiljevic S., Glamocic D., Jajic I., Cupina B., Katic S., Milic D., Mikic V. 2008. Fibre fractions of red clover (Trifolium pratense L.) at different harvests over two seasons. Biodiversity and animal feed, EGF, Grassland Sciences in Europe, 13, 510-513. 